\title{
EFFICIENCY EVALUATION OF COOPERATION BETWEEN TRANSPORT ENTERPRISES AND HIGHER EDUCATION INSTITUTIONS IN THE TRANSPORT AND LOGISTICS CLUSTER
}

\author{
Maryna Kovbatiuk', Vladyslava Shevchuk²
}

\begin{abstract}
The processes of formation and efficiency evaluation of the transport and logistics clusters' operation as a tool of national transport competitiveness, possibility to attract investment to the field, in order to reach a high point of innovation development, are of a great interest nowadays. All mentioned above make additional requests to the modern specialists in the transport industry. It is possible to solve this problem as a result of cooperation between transport enterprises and higher education institutions in the process of cluster operation. Thus, the subject of research is effective cooperation between transport enterprises and higher education institutions in the process of cluster structures' cooperation. The aim of the research is the development of an integrated index of operating efficiency evaluation of transport enterprises and higher education institutions to evaluate its cooperation under the conditions of operation of transport and logistics cluster (TLC). Methodology. In the research process, the methods of scientific knowledge such as analysis and synthesis were used in studying of the activity of self-supporting separated subdivision of Kiliya Shipbuilding and Repair Yard of Private JointStock Company "Ukrainian Danube Shipping Company" and State University of Infrastructure and Technologies in 2015-2017. Economic-mathematical methods were used to make integrated index calculation of operating efficiency evaluation of transport enterprise and higher education institute, value scale determination of the integrated index of operating efficiency evaluation of the clusters' entity. The expert evaluation method is used to define the values, characterized operation of transport enterprises and higher education institutions under the conditions of their cooperation within TLC and their significance. Method of scientific abstract is applied to come to theoretical general conclusions. The system approach is the main one in the research. Results. In the article, the methodological approach was used, it includes value system determination based on the expert evaluation, method of integrated index calculation and value scale development of an integrated index to evaluate performance efficiency of transport enterprises and higher education institutions under the conditions of their cooperation in transport and logistics cluster. This approach was applied on the example of the activity of self-supporting separated subdivision of Kiliya Shipbuilding and Repair Yard of Private Joint-Stock Company "Ukrainian Danube Shipping Company" and State University of Infrastructure and Technologies. It is determined that entities of transport and logistics cluster can achieve a general positive economic impact. Practical implications. Practical consequences are connected with the opportunity to use suggested methodological approach to make the calculation of entities' efficiency as a result of their cooperation in the cluster. The practicability of the cooperation between transport enterprises and educational institutions in the transport and logistics cluster in this research is proved by the opportunity to get a lot of advantages as a result of this cooperation, by the positive change of main operating index of the cluster's members. It is base for the development of further enterprise development strategy, proved by a jury of opinion and calculated integrated index of the effectiveness of their activity. Value/originality. Originality lies in the development of scientifically-grounded formulas for integrated index calculation of operating efficiency evaluation of transport enterprises and higher education institutions in the transport and logistics cluster and opportunity to identify efficiency level of their cooperation according to developed value scale.
\end{abstract}

Key words: transport and logistics cluster, transport enterprises, higher education institutions, cluster entities' cooperation, integrated index of efficiency evaluation.

JEL Classification: C13, D61, R49

Corresponding author:

${ }^{1}$ State University of Infrastructure and Technologies, Ukraine.

E-mail:mvkov@duit.edu.ua

${ }^{2}$ State University of Infrastructure and Technologies, Ukraine.

E-mail: shevchuk_vo@duit.edu.ua 


\section{Introduction}

Under the conditions of globalization and integration to the European Union, the processes of economics reformation of Ukraine have to form a new attitude type between entities and to develop also new implementation mechanisms of their economic interests, one of them is clustering. National competitiveness increase is a pre-condition in forming an effective economic system of any country. According to the global experience and conclusions of Ukrainian scientists, the main direction of strategic changes in the economy of Ukraine is a structural reformation of regional economics and operating of active investment policy focused on the development of modern industry and providing of transport services with the help of transport and logistics clusters (TLC).

Formation of the transport and logistics clusters is an efficient tool to increase the competitiveness of the national economy by means of costs minimization in the field of transport and logistics (Chupaylenko, 2013). Thus, the processes of formation and efficiency evaluation of transport and logistics clusters as a tool of national transport competitiveness, providing facilities to attract investment to the field in order to achieve the high level of innovation development are of a great interest.

All mentioned above make additional requests to the modern specialists in the transport industry. It is possible to solve this problem as a result of cooperation between transport enterprises and higher education institutions in the process of cluster operation. Thus, the subject of research is effective cooperation between transport enterprises and higher education institutions in the process of cluster structures' cooperation.

The aim of the research is the development of an integrated index of operating efficiency evaluation of transport enterprises and higher education institutions to evaluate its cooperation under the conditions of operation of transport and logistics cluster (TLC).

Methodology. In the research process, the methods of scientific knowledge such as analysis and synthesis were used in studying of the activity of self-supporting separated subdivision of Kiliya Shipbuilding and Repair Yard of Private Joint-Stock Company "Ukrainian Danube Shipping Company" and State University of Infrastructure and Technologies in 2015-2017. Economic-mathematical methods were used to make integrated index calculation of operating efficiency evaluation of transport enterprise and higher education institute, value scale determination of the integrated index of operating efficiency evaluation of the clusters' entity. The expert evaluation method is used to define the values, characterized operation of transport enterprises and higher education institutions under the conditions of their cooperation within TLC and their significance. Method of scientific abstract is applied to come to theoretical general conclusions. The system approach is the main one in the research.

\section{Literature review}

A considerable contribution to the development of theory and methodology clustering is made by the famous scientist M. Porter. He considered that enterprises of separate industries can be located in the particular regions of the country, have an active impact on the market entities, within they cooperate - suppliers, consumers, and competitors. In such a way, enterprises increase their competitiveness and as a result of such cooperation, a synergistic effect is appeared (Porter, 2006).

Such issues as particulars, advantages of the clusters' formation, grounding of necessity of clusters' creation in Ukraine are considered in the researches of P. T. Bubenko (Bubenko, 2009), V. Heyets (Heyets, 2008), N. G. Kanishchenko (Kanishchenko, 2006), U. E. Kirilov (Kirilov, 2013), I. O. Martynyak (Martynyak, 2008), S. V. Onishko (Onishko, 2010), S. I. Sokolenko (Sokolenko, 2004), and others.

Transport and logistics clusters as a category, their role and essence, problems of functioning and development are thoroughly studied by leading Ukrainian scientists as O. O. Karpenko (Karpenko, 2015), O. M. Polyakova (Polyakova, 2009), I. G. Smirnov (Smirnov, 2008, Smirnov, 2012), O. A. Chupaylenko (Chupaylenko, 2013). However, the research papers are outlined with an efficiency evaluation of the cluster's functioning or transport and logistics enterprises in the cluster structure.

Therefore, research issue on the functioning of transport and logistics clusters is relatively new in the scientific literature. Simultaneously, a variety of aspects, including efficiency evaluation of enterprise activity and educational institutions as the result of their cooperation, is poorly considered and needs further studying. The necessity in grounded work on this aspect determines the choice of a research line.

\section{The main material of the research}

Practicability and efficiency in forming and functioning of cluster in the transport and logistics industry are based on the operating index of the logistics centres, logistics companies, storage facilities, suppliers, customers, financial lending institutions, design and scientific-research organizations, consulting and audit firms, insurance companies and forwarding agencies, labour forces and financial resources, having an effect on the level increase in management decision making: cost minimization, risk mitigation, helped to use in full resource potential and opportunities in the market for transport services.

The efficiency of the transport and logistics cluster is a relative index, showing the relationship between results and costs, connected with the usage of production goods, labour power, entrepreneurial abilities by transport services, providing of certain 


\section{Expert evaluation; with its help indices were identified. They show the operation of transport enterprises and higher education institutions under the conditions of their cooperation in TLC and significance.}

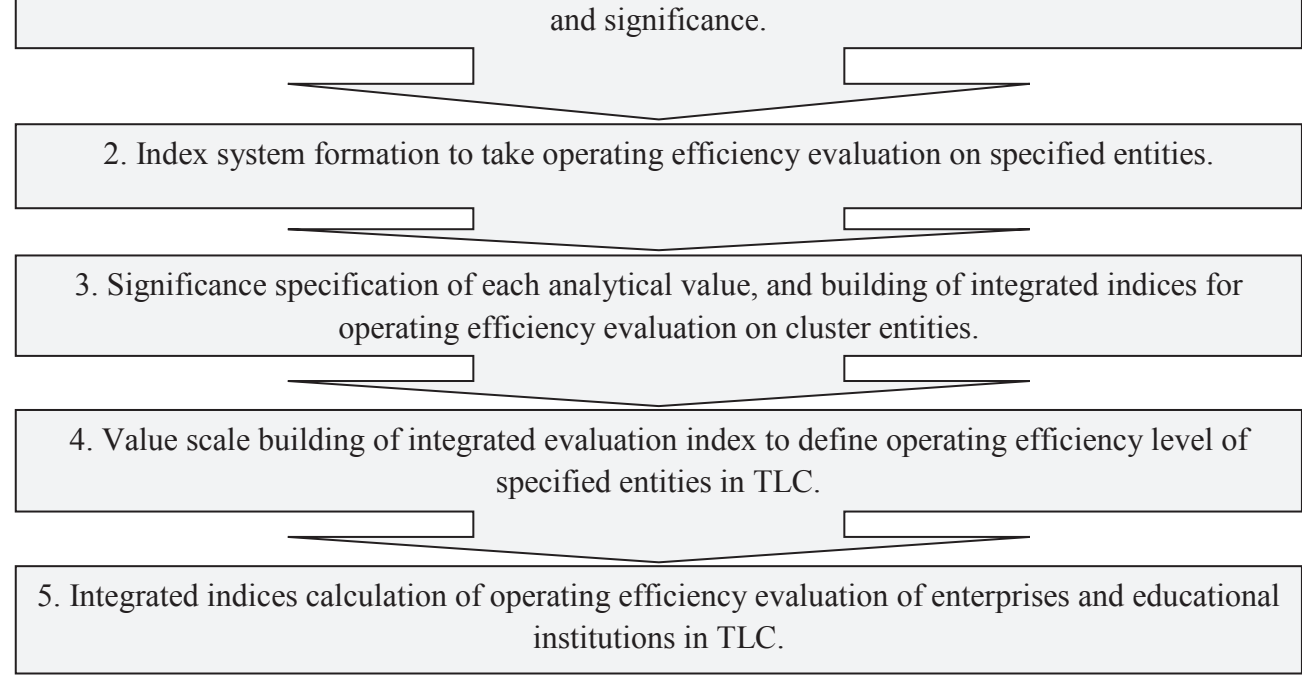

Figure 1. The process of operating efficiency evaluation of TLC under the conditions of their cooperation Source: developed by the authors

quality under the conditions of limited resources and unlimited wants. Therefore, an efficiency increase of the operation of transport enterprises and their association with other enterprises in the transport and logistics cluster provides a new development level of relationship between enterprises of the region, including transport and logistics technologies, improvement of investment attraction and territory (Chupaylenko, 2014).

There is a difficult relationship system among participants in the cluster, providing important synergetic effect from its functioning and playing a key role in the formation and maintaining of competitive strength. Relationships among cluster members are different and dynamic.

After establishing relevant relationships between TLC entities, there is a need for efficiency evaluation of their cooperation with the help of an integrated index of operating efficiency in each of them under the conditions of cluster functioning.

The target of evolution is to define the current level of social and economic efficiency of the management system and to achieve eventual results of cluster entity's activity.

The research was conducted on the basis of the methodological approach; its sequencing is shown in Figure 1. It includes index system specification based on the expert evaluation, methods of integral coefficient calculation and development of the value scale of the integrated index of operating efficiency on specified cluster entities.

On the first stage, based on the expert survey (employees of transport enterprises, shipping companies; managers of logistics companies and scientists of the higher education institutions etc.), there were indices identified for integrated indices specification in order to find operating efficiency evaluation of transport enterprise and higher education institute in the cluster, and also their significance was identified.

On the second stage, the analytical index system was formed from the most significant and informative indices. It is made for operating efficiency evaluation of transport enterprises and higher education institutions under the conditions of their cooperation in the transport and logistics cluster.

As a rule, in national practice, the index system is used to define the economic operating efficiency of enterprises. It shows us the relation between expenses and obtained results, i.e. impacts that could be obtained from the interactive system in the cluster. Taking into account that the main focus of the research is highquality staff training, the indices are identified to show the result of their usage (Table 1).

Operating efficiency of higher education institutions is better to evaluate with the help of indices, indicated both educational and scientific constituent of their activity. The system of corresponding figures is set out in Table 2.

On the third stage to divide relative share among specified indices (for further integrated index calculation of operating efficiency of cluster entities), the authors made a survey of 10 Ukrainian experts in clustering field, business-structures, state infrastructure authorities etc. Survey findings are set out in Table 3 and Table 4.

Calculation data show us $38 \%$ of profit ration; $14.5 \%$ of labour productivity index; $17 \%$ of employment capacity 
Vol. 4, No. 5, 2018

Table 1

Indices of operating efficiency evaluation of transport enterprises

\begin{tabular}{|c|c|c|}
\hline Index & Calculation formula & Specification \\
\hline Profit ratio & $k_{P}=\frac{\operatorname{Pr}}{C}$ & $\begin{array}{l}\boldsymbol{P r} \text { - profit from realization of products (works, services), } \\
\text { thousand UAH; } \\
\boldsymbol{C} \text { - costs, thous. UAH }\end{array}$ \\
\hline Labour productivity index & $I_{L P}=\frac{L P_{1}}{L P_{0}}$ & $\begin{array}{l}\mathbf{L} \boldsymbol{P}_{1}-\text { value of labour productivity of accounting period, thous. } \\
\text { UAH; } \\
\mathbf{L} \boldsymbol{P}_{0}-\text { value of labour productivity of base period, thous. UAH }\end{array}$ \\
\hline Employment capacity coefficient (staff) & $k_{e c}=\frac{Q e_{r}}{Q e_{t}}$ & $\begin{array}{l}\boldsymbol{Q} \boldsymbol{e}_{r}-\text { number of regular employees; } \\
\boldsymbol{Q \boldsymbol { e } _ { t }}-\text { total number of employees (permanent employed }+ \\
\text { temporary employed). }\end{array}$ \\
\hline Workplace providing coefficient & $k_{w p}=\frac{Q_{u}}{Q_{p}}$ & $\begin{array}{l}\boldsymbol{Q}_{u}-\text { number of used workplaces; } \\
\boldsymbol{Q}_{p}-\text { number of possible workplaces. }\end{array}$ \\
\hline Coefficient of educational-qualification staff level & $k_{e q l}=\frac{Q_{\text {ste }}}{Q_{\text {she }}}$ & $\begin{array}{l}\boldsymbol{Q}_{\text {ste }}-\text { number of staff with transport education, people; } \\
\boldsymbol{Q}_{\text {she }}-\text { number of staff with higher education, people. }\end{array}$ \\
\hline
\end{tabular}

Source: developed by the authors

Table 2

Indices of operating efficiency evaluation of higher education institutions

\begin{tabular}{|c|c|c|}
\hline Index & Calculation formula & Specification \\
\hline Students' number index & $I_{s}=\frac{Q s_{1}}{Q s_{0}}$ & 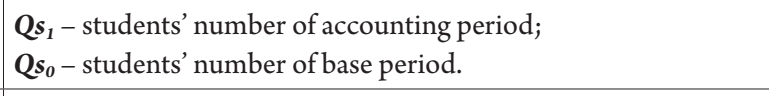 \\
\hline Employment coefficient & $k_{e}=\frac{Q s_{e}}{Q s_{g}}$ & $\begin{array}{l}\mathbf{Q \boldsymbol { s } _ { e }}-\text { number of employed students; } \\
\mathbf{Q \boldsymbol { s } _ { g }}-\text { number of graduated students. }\end{array}$ \\
\hline Graduation coefficient & $k_{g}=\frac{Q s_{g}}{Q s_{a}}$ & 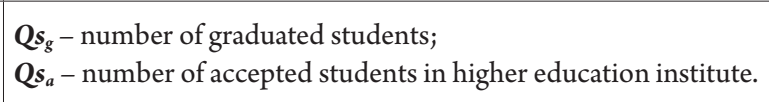 \\
\hline Part of economic contract paper subjects & $k_{E C P S}=\frac{E C P S}{P S}$ & $\begin{array}{l}\text { ECPS - number of economic contract paper subjects; } \\
\text { PS - number of scientific-research subjects (economic contract + } \\
\text { state-financed). }\end{array}$ \\
\hline $\begin{array}{l}\text { Budgeting coefficient for economic contract paper } \\
\text { subjects }\end{array}$ & $k_{B E C P S}=\frac{B_{E C P S}}{B_{P S}}$ & $\begin{array}{l}\boldsymbol{B}_{E C P S} \text { - budget volume for economic contract paper subjects, } \\
\text { thous. UAH; } \\
\boldsymbol{B}_{P S} \text { - budget volume for scientific-research subjects (economic } \\
\text { contract + state-financed), thous. UAH. }\end{array}$ \\
\hline
\end{tabular}

Source: developed by the authors

Table 3

Expert survey findings on indices significance of operating efficiency evaluation of transport enterprise in TLC

\begin{tabular}{|c|c|c|c|c|c|}
\hline Expert & Profit ratio & LP index & $\begin{array}{c}\text { Employment } \\
\text { coefficient }\end{array}$ & $\begin{array}{c}\text { Workplace providing } \\
\text { coefficient }\end{array}$ & $\begin{array}{c}\text { Coefficient } \\
\text { of educational- } \\
\text { qualification staff level }\end{array}$ \\
\hline Expert 1 & 0,3 & 0,1 & 0,2 & 0,2 & 0,2 \\
\hline Expert 2 & 0,3 & 0,1 & 0,3 & 0,2 & 0,1 \\
\hline Expert 3 & 0,5 & 0,25 & 0,1 & 0,1 & 0,05 \\
\hline Expert 4 & 0,4 & 0,1 & 0,15 & 0,2 & 0,15 \\
\hline Expert 5 & 0,3 & 0,25 & 0,2 & 0,05 & 0,2 \\
\hline Expert 6 & 0,4 & 0,1 & 0,2 & 0,1 & 0,2 \\
\hline Expert 7 & 0,5 & 0,1 & 0,1 & 0,15 & 0,15 \\
\hline Expert 8 & 0,3 & 0,15 & 0,2 & 0,05 & 0,3 \\
\hline Expert 9 & 0,5 & 0,15 & 0,1 & 0,05 & 0,2 \\
\hline Expert 10 & 0,3 & 0,15 & 0,15 & 0,15 & 0,25 \\
\hline $\begin{array}{c}\text { Average value } \\
\text { of index relative share }\end{array}$ & 0,38 & 0,145 & 0,17 & 0,125 & 0,18 \\
\hline
\end{tabular}

Source: developed by the authors 
Table 4

Expert survey findings on indices significance of operating efficiency evaluation of higher education institutions in TLC

\begin{tabular}{|c|c|c|c|c|c|}
\hline Expert & $\begin{array}{c}\text { Students' number } \\
\text { index }\end{array}$ & $\begin{array}{c}\text { Employment } \\
\text { capability coefficient }\end{array}$ & $\begin{array}{c}\text { Graduation } \\
\text { coefficient }\end{array}$ & Part of ECPS & $\begin{array}{c}\text { Budgeting coefficient } \\
\text { for ECPS }\end{array}$ \\
\hline Expert 1 & 0,3 & 0,15 & 0,1 & 0,2 & 0,25 \\
\hline Expert 2 & 0,35 & 0,1 & 0,05 & 0,3 & 0,2 \\
\hline Expert 3 & 0,5 & 0,2 & 0,1 & 0,1 & 0,1 \\
\hline Expert 4 & 0,4 & 0,15 & 0,05 & 0,15 & 0,25 \\
\hline Expert 5 & 0,35 & 0,1 & 0,1 & 0,2 & 0,25 \\
\hline Expert 6 & 0,3 & 0,2 & 0,1 & 0,2 & 0,15 \\
\hline Expert 7 & 0,45 & 0,15 & 0,1 & 0,15 & 0,25 \\
\hline Expert 8 & 0,4 & 0,05 & 0,1 & 0,2 & 0,2 \\
\hline Expert 9 & 0,35 & 0,1 & 0,15 & 0,2 & 0,15 \\
\hline Expert 10 & 0,3 & 0,1 & 0,15 & 0,185 & 0,215 \\
\hline $\begin{array}{c}\text { Average value } \\
\text { of index relative share }\end{array}$ & 0,37 & 0,13 & 0,1 & \\
\hline
\end{tabular}

Source: developed by the authors

coefficient; $12.5 \%$ of workplace providing coefficient; $18 \%$ of the coefficient of educational-qualification staff level have an effect on the integrated index of operating efficiency at the transport enterprise.

Expert evaluation consistency was estimated by Pearson $\chi^{2}$ criterion (Vasylenko, Sencha, 2011). Experimental value is more than a critical one, that is why we can consider obtained expert evaluation with a probability value of 0,95 as finalized.

On basis of obtained data, we generate an integrated index for operating efficiency evaluation of transport enterprise $\left(\boldsymbol{I}_{T E}\right)$ as a result of cooperation with higher education institution in transport and logistics cluster:

$$
I_{T E}=0,38 \cdot k_{p}+0,145 \cdot I_{L P}+0,17 \cdot k_{e c}+0,125 \cdot k_{w p}+0,18 \cdot k_{e q l}(1)
$$

It is proved that $37 \%$ of students' number index, $13 \%$ of employment capability coefficient, $10 \%$ of graduation coefficient, $18.5 \%$ of a part of economic contract paper subjects, $21.5 \%$ of budgeting coefficient for economic contract paper subjects have an impact on the integrated index of operating efficiency in higher education institute.

Reliability of obtained findings is evaluated in a similar way and proved by finalizing expert assessment.

As a result, we get the following formula of the integrated index for operating efficiency evaluation in higher education institute $\left(\boldsymbol{I}_{\boldsymbol{H E I}}\right)$ in cooperation with transport enterprise in transport and logistics cluster:

$$
I_{H E I}=0,37 \cdot I_{s}+0,13 \cdot k_{e}+0,1 \cdot k_{g}+0,185 \cdot k_{E C P S}+0,215 \cdot k_{B E C P S}(2)
$$

Value of integrated indices of operating efficiency evaluation of enterprises in TLC, calculated by suggested formulas including relative share each of the coefficients, is the basis for proving cooperation practicability of considered entities in the cluster.

To identify operating efficiency level of entities in TLC, we build value scale of integrated indices on the fourth stage. To achieve it, we use dispersion analysis of alternative and specified features and define average quadratic deviation in alternative distribution number of integral coefficients of indices significance.

Quantified variability is figured by the low reference value, indicated as 0 . Highest value can be 1 and more, because a part of indices, according to that integrated indices of operating efficiency of cluster entities are calculated, focusing on 1 , and only a few coefficients can increase 1 under particular conditions.

Then $p$ - a part of units of integral coefficients of group weight that we calculate by the formula below and get the highest critical value on a scale value of the integrated index for transport enterprise and higher education institute:

$p=\sqrt[5]{a_{1} \cdot a_{2} \cdot a_{3} \cdot a_{4} \cdot a_{5}}$

$a_{i}, i=\overline{1,5}$ - integral coefficients of group weight.

Accordingly,

$$
q=1-p
$$

Thus, the average quadratic deviation of integral weight coefficients from the reference value is calculated by the formula:

$$
\sigma=\sqrt{p \cdot q}
$$

We obtain the following result thanks to the calculations above:

$$
\begin{aligned}
& p_{T E}=\sqrt[5]{0,38 \cdot 0,145 \cdot 0,17 \cdot 0,125 \cdot 0,18}=0,1839 \\
& \text { consequently, } q_{T E}=1-0,18=0,82 \\
& p_{H E I}=\sqrt[5]{0,37 \cdot 0,13 \cdot 0,1 \cdot 0,185 \cdot 0,215}=0,1804 \\
& \text { consequently, } q_{H E I}=1-0,18=0,82
\end{aligned}
$$

As we can see, part of units of integral coefficients of group weight for transport enterprises and higher education institutions is the same in this research. Consequently, for both cluster entities, the results from the average quadratic deviation of integral weight coefficients, and accordingly, a scale value of the integrated index of operating efficiency are the same.

$$
\text { Thus, } \sigma=\sqrt{0,18 \cdot 0,82}=0,38 \text {. }
$$


The obtained result from average quadratic deviation of integral weight coefficients give us the opportunity to define course length of sufficient level of operating efficiency in TLC entity and it reaches 0,38 .

Having used method $3 \sigma$, we build scale in units of standard deviation parts, having determined interval scale as $\frac{1}{2} \sigma=0,19$ and we obtain course length of the next level (low). Then scaling interval of operating efficiency of cluster entity is calculated as $2 \cdot \frac{1}{2} \sigma=\sigma=0,38$, made the difference between upper bound of low and sufficient levels, and the difference between lower bound of low level and upper bound of sufficient level has to be $3 \cdot \frac{1}{2} \sigma=\frac{3}{2} \sigma=0,57$.

Taking into account reported values, we build scale for magnitude estimation of the integrated index of operating efficiency in cluster entities (Table 5).

Table 5

Value scale of the integrated index of operating efficiency evaluation at transport enterprise and in higher education institution in TLC

\begin{tabular}{|c|c|}
\hline Indicator value & Specification \\
\hline Less than 0,19 & $\begin{array}{c}\text { Critical level of operating efficiency } \\
\text { of TLC entity }\end{array}$ \\
\hline From 0,2 to 0,39 & $\begin{array}{c}\text { Low level of operating efficiency } \\
\text { of TLC entity }\end{array}$ \\
\hline From 0,4 to 0,77 & $\begin{array}{c}\text { Sufficient level of operating efficiency } \\
\text { of TLC entity }\end{array}$ \\
\hline From 0,78 and more & $\begin{array}{c}\text { High level of operating efficiency } \\
\text { of TLC entity }\end{array}$ \\
\hline
\end{tabular}

Source: developed by the authors
This scale helps us to identify operating efficiency level of transport enterprise or higher education institution as a result of their cooperation in the cluster.

On the fifth stage, we evaluate the operating efficiency of transport enterprises and higher education institutions in TLC by means of corresponding figures calculation.

\section{Results}

We use suggested methodological approach on a specific example.

Having analysed the potential capacity of each region of Ukraine on the creation of a transport and logistics cluster, border areas draw our attention. Their centres are large cities and urban agglomerations, international transport corridors pass through them.

We consider the creation of transport and logistics cluster in the Danube region is long-range for the development of international cooperation and experience exchange, and also for meeting EU requirements.

Let us make it clear, what transport enterprises and educational institutions can be its constituent part (Table 6). The Danube region has a lot of water transport enterprises, among them are Kiliya Shipbuilding and Repair Yard, PJSC "Ukrainian Danube Shipping Company", PJSC "Danube Shipping Management Service” in Izmail, Vilkovo Marine Shipyard Repair and Maintenance, branch of JSSC "Ukrrichflot". These companies can form a business association at the premises of shipbuilding and repair enterprises.

Table 6

Main participants of transport and logistics cluster of Danube region

\begin{tabular}{|c|c|}
\hline Line of activity & Name of enterprise, organization, institution \\
\hline Transport companies & $\begin{array}{l}\text { 1) Zovnishtrans, LLC } \\
\text { 2) Ust-Danube Waterway, SE } \\
\text { 3)Ukrainian Danube Shipping Company, PJSC }\end{array}$ \\
\hline Freight-forwarding firms & $\begin{array}{l}\text { 4) Avtologistika, LLC } \\
\text { 5) Dunay-Multi-Service, LLC } \\
\text { 6) SWTRANS, LLC } \\
\text { 7) Odessa Regional Chamber of Commerce and Industry }\end{array}$ \\
\hline Repair and maintenance enterprises & $\begin{array}{l}\text { 8) Kiliya Shipbuilding and Repair Yard } \\
\text { 9) Danube Shipping Management Service, PJSC in Izmail } \\
\text { 10) Vilkovo Marine Shipyard Repair and Maintenance } \\
\text { 11) Branch of Ukrrichflot, JSSC }\end{array}$ \\
\hline Ports, railway stations & $\begin{array}{l}\text { 12) Ust-Danube Commercial Sea Port } \\
\text { 13) Izmail Commercial Sea Port } \\
\text { 14) Reni Commercial Sea Port } \\
\text { 15) Izmail Airport }\end{array}$ \\
\hline Educational institutions & $\begin{array}{l}\text { 16) State University of Infrastructure and Technologies } \\
\text { 17) Izmail Maritime Institute }\end{array}$ \\
\hline Insurance companies & $\begin{array}{l}\text { 18) PJ Stock Insurance Company “INGO Ukraine” } \\
\text { 19) BC KRONA, PJSC }\end{array}$ \\
\hline Banks & 20) Privatbank, PJSC \\
\hline Database & $\begin{array}{l}\text { 21) Ukrainian transport portal UkrTransport } \\
\text { 22) Transportation Information system Olantrans }\end{array}$ \\
\hline Government support & 23) Ministry of Infrastructure of Ukraine \\
\hline
\end{tabular}

Source: developed by the authors 
Secondly, there are such companies as Ust-Danube Commercial Sea Port, Kiliya Port Station, Izmail Commercial Sea Port, Reni Commercial Sea Port; SWTRANS LLC, Zovnishtrans LLC, Ust-Danube Waterway, Izmail Airport, Odesa Regional Chamber of Commerce and Industry.

Thirdly, among educational institutions, where the future specialists of transport industry study, are Izmail Maritime Institute and separated subdivisions of State University of Infrastructure and Technologies (former Kyiv State Maritime Academy named after Hetman Petro Konashevych-Sahaidachny), in particular, Danube faculty of Maritime and River Transport (in Izmail) and Kiliya Transport College (in Kiliya).

To make an assessment, we have chosen selfsupporting separated subdivision of Kiliya Shipbuilding and Repair Yard of Private Joint-Stock Company "Ukrainian Danube Shipping Company" (SSS "KSRY" PJSC "UDSC") and State University of Infrastructure and Technologies (SUIT) future specialists study at. Analytical and integrated indices of their performance are calculated and set out in Table 7.

Table 7

Performance indices of KSRY and UDSC in 2015-2017

\begin{tabular}{|c|c|c|c|}
\hline № & Indices & 2015 & 2017 \\
\hline \multicolumn{4}{|c|}{ Kiliya Shipbuilding and Repair Yard } \\
\hline 1 & Profit ratio & 0,124 & 0,012 \\
\hline 2 & Labour productivity index & 3,06 & 0,98 \\
\hline 3 & Employment capacity coefficient & 0,99 & 0,95 \\
\hline 4 & Workplace providing coefficient & 0,11 & 0,08 \\
\hline \multirow[t]{2}{*}{5} & $\begin{array}{l}\text { Coefficient of educational- } \\
\text { qualification staff level }\end{array}$ & 0,63 & 0,65 \\
\hline & Integrated efficiency index & $\mathbf{0 , 7 8}$ & $\mathbf{0 , 4 3}$ \\
\hline \multicolumn{4}{|c|}{ State University of Infrastructure and Technologies } \\
\hline 1 & Students' number index & 0,99 & 1,02 \\
\hline 2 & Employment coefficient & 0,8 & 0,85 \\
\hline 3 & Graduation coefficient & 0,95 & 0,97 \\
\hline 4 & $\begin{array}{l}\text { Part of economic contract paper } \\
\text { subjects }\end{array}$ & 0,5 & 0,5 \\
\hline 5 & $\begin{array}{l}\text { Budgeting coefficient for } \\
\text { economic contract paper subjects }\end{array}$ & 0,09 & 0,5 \\
\hline & Integrated efficiency index & 0,67 & 0,78 \\
\hline
\end{tabular}

Source: developed by the authors

Kiliya Shipbuilding and Repair Yard is having lost positions by selected indices during the analysed period. For example, profit ratio is decreased by 11,2 points, labour productivity index is down by 2,08 , employment capacity coefficient - by 0,04 and workplace providing coefficient - by 0,03 . However, the coefficient of educational-qualification staff level is increased by 0,02 points. And it makes possible to come to a conclusion about the unstable state of the enterprise operation.

Conducted research on the operating efficiency of the State University of Infrastructure and Technologies shows us the increase of all main indices: students' number index is up by 0,03 points, employment coefficient - by 0,05 , graduation coefficient $-0,02$, budgeting coefficient of economic contract paper topics - by 0,41 .

It is worth mentioning, development enterprises and those with relaxation, having got united in the transport and logistics cluster, can achieve positive economic effect thanks to mutual support among all participants of the clustering process. That is the main advantage of clusters. Because of advantages from enterprise incorporating in TLC, including expert commentary and researches of the leading scientists, it is expected the following increase of main operating indices of cluster entities in clustering: industrial production is increased by $6.5 \%$; part of innovative-active enterprises in total amount from industries is increased to $30.3 \%$; rate of development of transport infrastructure is up to $15 \%$; increase of cargo transportation is up to $8.5 \%$; investment activity is up to $5.3 \%$.

Taking this trend into account, the predictable indices of operation in KSRY and UDSC were calculated. Based on these values, the calculation of the integrated index of its operating efficiency as members of transport and logistics cluster for 2022 was made (Table 8). Forecasting period consists of four years because it is impossible to train skilled staff for KSRY (training for specialists according to shortened program takes three years, whereas a complete program is developed for four years) and do effective teamwork among considered entities.

Table 8

Predictable indices of operation in KSRY and UDSC

\begin{tabular}{|c|l|c|}
\hline \multicolumn{1}{|c|}{ № } & \multicolumn{1}{|c|}{ Kiliya Shipbuilding and Repair Yard } \\
\hline \multicolumn{3}{|c|}{2022} \\
\hline 1 & Profit ratio & 0,15 \\
\hline 2 & Labour productivity index & 1,53 \\
\hline 3 & Employment capacity coefficient & 1 \\
\hline 4 & Workplace providing coefficient & 0,55 \\
\hline 5 & $\begin{array}{l}\text { Coefficient of educational-qualification } \\
\text { staff level }\end{array}$ & 0,89 \\
\hline 6 & Integrated efficiency index & $\mathbf{0 , 6 8}$ \\
\hline \multicolumn{2}{|l|}{ State University of Infrastructure and Technologies } \\
\hline 1 & Students' number index & 1,14 \\
\hline 2 & Employment coefficient & 0,9 \\
\hline 3 & Graduation coefficient & 0,98 \\
\hline 4 & Part of economic contract paper subjects & 0,65 \\
\hline 5 & $\begin{array}{l}\text { Budgeting coefficient for economic } \\
\text { contract paper subjects }\end{array}$ & 0,7 \\
\hline 6 & Integrated efficiency index & $\mathbf{0 , 9}$ \\
\hline
\end{tabular}

Source: developed by the authors

Obtained predictable values from integrated indices of members' activity in transport and logistics cluster as a result of their cooperation after joining cluster are proof of: 
- integrated index of operating efficiency of Kiliya Shipbuilding and Repair Yard reaches 0,68, therefore, it is within the scope of 0,4 and 0,77 and demonstrates sufficient level of the operating efficiency entity in TLC; - integrated index of operating efficiency of State University of Infrastructure and Technologies reaches 0,9, i.e. it is within the scope of 0,78 and more and demonstrates a high level of the operating efficiency level in TLC.

Thus, joining the cluster and further cooperating of entities enable to achieve both individual and synergetic effect.

\section{Conclusions}

Therefore, based on made calculations, we come to the conclusion that cooperation between transport enterprises and higher education institutions as TLC entities will have a positive impact.
Moreover, conducted research is a proof of practicability in cooperation between transport enterprises and higher education institutions in transport and logistics cluster and makes emphasis on the opportunity to get a lot of advantages from its cooperation, positive change in main indices of cluster members' activity.

Suggested indices of operating efficiency evaluation of transport enterprises and higher education institutions in the cluster enable us to make a forecast about the impact from cooperation for similar entities in longrange transport and logistics clusters in other regions of Ukraine, for instance, in Kyiv and Mykolaiv. After that, it is possible to identify the level of these indices by developed value scale and give well-grounded recommendations on joining of selected entities the cluster.

\section{References:}

Bubenko, P. T., Snisarenko, O. B. (2009). Innovacijnyj rozvytok regioniv [Innovative development regions]. Kharkiv, Vyd-vo «Fort». (in Ukrainian)

Chupaylenko, O. A. (2013). Rozvytok transportno-logistychnyh klasteriv v Ukraini [Development of transportlogistic clusters in Ukraine]. Retrieved from: http://publications.ntu.edu.ua/visnyk/28_2013/535-544.pdf

Chupaylenko, O. A. (2014). Transkordonni transportno-logistychni klastery ta transkordonni objednannja $\mathrm{v}$ Ukrai'ni [Cross-border transport-logistic clusters and cross-border associations in Ukraine]. Retrieved from: http://publications.ntu.edu.ua/upravl_progect/2014_14_tech/266.pdf

Heyets, V. M. (2008). Klastery i merezhevi struktury v ekonomici - tema dosyt cikava, ale na sogodni shhe do kincja ne vyvchena... [Clusters and network structure in the economy - the topic is interesting enough, but it is still not fully understood .... Ekonomist, 10, 10-11.

Kanishchenko, N. G. (2006). Klastery v systemi nacionalnoi konkurentospromozhnosti [Clusters in the national competitiveness]. Visnyk of the KNU. Series Economics, 85, 14-16.

Karpenko, O. O. (2015). Mehanizm klasteryzacii transportno-logistychnyh pidpryjemstv [Mechanism of clustering of transport-logistic enterprises]. Efektyvna ekonomika, no. 10. Retrieved from: http://www.economy.nayka.com.ua/ ?op $=1 \& \mathrm{z}=4428$

Kirilov, Y. E. (2013). Klastery jak instrument pidvyshhennja konkurentospromozhnosti nacionalnoi ekonomiky v umovah globalizacii [Clustering as a tool to improve the competitiveness of national economies in a globalizing]. Efektyvna ekonomika, no. 12. Retrieved from: http://www.economy.nayka.com.ua/?op=1\&z=2608

Martynyak, I. O. (2008). Formuvannja klasternoi polityky jak mehanizmu vdoskonalennja infrastruktury funkcionuvannja malogo i serednogo innovacijnogo biznesu v regioni [Formation of cluster policy as a mechanism for improving the infrastructure operation of small and medium-sized innovative businesses in the region]. Regional economy, 4, 54-62.

Onishko, S. V. (2010). Derzhavne reguljuvannja klasteryzacii ekonomiky jak naprjamok rozbudovy nacionalnoi innovacijnoi modeli [Clustering State regulation of the economy as a way of building a national innovation model]. Actual problems of the economy, 11, 55-61.

Polyakova, A. M. (2009). Globalizacija transportno-logistychnyh system u svitovij ekonomici [Globalization transport-logistics systems in the world economy]. Bulletin of Economics and Transport Industry UkrDAZT, 26, 32-34. Porter, M. (2006). Konkurencija [Competition]. Moscow, Publishing house «Williams». (in Russian)

Smirnov, I. G. (2012). Transportno-logistychni klastery v JeS ta integracija Ukrainy v ci struktury [Transportlogistic clusters in the EU and integration of Ukraine in this structure]. Retrieved from: http://ea.donntu.edu.ua/ bitstream/123456789/19844/1/66_Smirnov.pdf

Smirnov, I. G., Kosarev, A. V. (2008). Transportna logistyka [Transport Logistics]. Kyiv, TSUL. (in Ukrainian) Sokolenko, S. I. (2004). Klastery v globalnij ekonomici [Clusters in the global economy]. Kyiv, Logos. (in Ukrainian) Vasylenko, O. A., Sencha, I. A. (2011). Matemachno-statystychni metody analizu u prykladnyh doslidzhennjah: navch. posib. [Mathematical-statistical methods of analysis in applied research: teaching. manual]. Odessa, ONAT them. O. S. Popov. (in Ukrainian) 